Chaplin, G.R. and K.J. Scott. 1980. Association of calcium in chilling injury susceptibility of stored avocados. HortScience 15:514-515.

Chaplin, G.R., R.B.H. Wills, and D. Graham. 1983. Induction of chilling injury in stored avocados with exogenous ethylene. HortScience 18:952-953.

Cohen, E. 1988. Commercial use of long-term storage of lemon with intermittent warming. HortScience 23:400.

Cohen, E., M. Shuali, and Y. Shalom. 1983. Effect of intermittent warming on the reduction of chilling injury of 'Villa Franca' lemon fruit stored at cold temperature. J. Hort. Sci. 58:593-598.

Fukushima, H., S. Nagao, and Y. Nozawa. 1979. Further evidence for changes in the level of palmitoyl-CoA desaturase during thermal adaptation in Tetrahymena pyriformis. Biochim. Biophys. Acta 572:178-182.

Hardenburg, R.E., A.E. Watada, and C.Y. Wang. 1986. The commercial storage of fruits, vegetables, and florist and nursery stocks. U.S. Dept. Agr., Agr. Hdbk. 66, Washington, D.C.

Hatton, T.T. 1990. Reduction of chilling injury with temperature manipulation, p. 269-280. In: C.Y. Wang (ed.). Chilling injury of horticultural crops. CRC Press, Boca Raton, Fla.

Ilker, Y. and L.L. Morris. 1975. Alleviation of chilling injury of okra. HortScience $10: 324$.

Jones, R.L., H.T. Freebairn, and J.F. McDonnell. 1978. The prevention of chilling injury, weight loss reduction, ripening retardation in banana. J. Amer. Soc. Hort. Sci. 103:219-221.

Kawada, K., T.A. Wheaton, A.C. Purvis, and W. Grierson. 1979. Levels of growth regulators and reducing sugars of 'Marsh' grapefruit peel as related to seasonal resistance to chilling injury. HortScience 14:446.

Kramer, G.F. and C.Y. Wang. 1989a. Reduction of chilling injury in zucchini squash by temperature management. HortScience 24:995-996.

Kramer, G.F. and C.Y. Wang. 1989b. Correlation of reduced chilling injury with increased spermine and spermidine levels in zucchini squash. Physiol. Plant. 76:479-484.

Lee, E.H., J.K. Byun, and G.L. Steffens. 1985. Increased tolerance of plants to $\mathrm{SO}_{2}$, chilling, and heat stress by a new GA biosynthesis inhibitor, paclobutrazol (PP333). Plant Physiol. 77(Suppl.):135.

Lipton, W.J. and Y. Aharoni. 1979. Chilling injury and ripening of 'Honey Dew' muskmelons stored at 2.5 or $5 \mathrm{C}$ after ethylene treatment at 20C. J. Amer. Soc. Hort. Sci. 104:327-330.

Lurie, S. and J.D. Klein. 1991. Acquisition of low-temperature tolerance in tomatoes by exposure to high-temperature stress. J. Amer. Soc. Hort. Sci. 116:1007-1012.

Lyons, J.M. and R.W. Breidenbach. 1987. Chilling injury, p. 305-326. In: J. Weichmann (ed.). Postharvest physiology of vegetables. Marcel Dekker, New York.

McDonald, R.E., W.R. Miller, and T.G. McCollum. 1990. Reducing chilling injury and decay of grapefruit by fungicides applied at high temperatures. HortScience 25:1084

Moline, H.E. and J. Teasdale. 1981. Some effects of calcium treatments on ripening rate and chilling injury of tomato fruit. Proc. 3rd Tomato Quality Wkshp., College Park, Md. p. 119-131.

Nakamura, R., A. Inaba, and T. Ito. 1985. Effect of cultivating conditions and postharvest stepwise cooling on the chilling sensitivity of eggplant and cucumber fruits. Sci. Rpt., Okayama Univ., Japan, Sci. Rpt. 66, p. 19-29.

Nordby, H.E. and R.E. McDonald. 1990. Squalene applied to grapefruit prevents chilling injury. HortScience 25:1094.

Pantastico, E.B., W. Grierson, and J. Soule. 1967. Chilling injury in tropical fruits: I. Bananas. Proc. Trop. Reg. Amer. Soc. Hort. Sci. 11:82-91.

Paull, R.E. 1990. Chilling injury of crops of tropical and subtropical origin, p. 17-36. In: C.Y. Wang (ed.). Chilling injury of horticultural crops. CRC Press, Boca Raton, Fla.

Pentzer, W.T. and P.H. Heinze. 1954. Postharvest physiology of fruits and vegetables. Annu. Rev. Plant Physiol. 5:205-224.

Raison, J.K. and G.R. Orr. 1990. Proposals for a better understanding of the molecular basis of chilling injury, p. 145-164. In: C.Y. Wang (ed.). Chilling injury of horticultural crops. CRC Press, Boca Raton, FL.

Rikin, A., D. Atsmon, and C. Gitler. 1979. Chilling injury in cotton: Prevention by abscisic acid. Plant Cell Physiol. 20:1537-1546.

Rikin, A. and A.E. Richmond. 1976. Amelioration of chilling injuries in cucumber seedlings by abscisic acid. Physiol. Plant. 38:95-97.

Schiffmann-Nadel, M., E. Chalutz, J. Waks, and F.S. Lattar. 1972. Reduction of pitting of grapefruit by thiabendazole during long-term cold storage. HortScience 7:394-395.

Senaratna, T., C.E. Mackay, B.D. McKersie, and R.A. Fletcher. 1988. Uniconazole-induced chilling tolerance in tomato and its relationship to antioxidant content. J. Plant Physiol. 133:56-61.

Shewfelt, R.L. 1992. Response of plant membranes to chilling and freezing, $p$. 192-219. In: Y.Y. Leshem (ed.). The plant membrane: A biophysical approach. Kluwer Press, Amsterdam.

Wade, N.L. 1979. Physiology of cool-storage disorders of fruits and vegetables, p. 81. In: J.M. Lyons, D. Graham, and J.K. Raison. (eds.). Low temperature stress in plants. Academic, New York.

Wang, C.Y. 1982. Physiological and biochemical responses of plants to chilling stress. HortScience 17:173-186.

Wang, C.Y. 1991. Effect of abscisic acid on chilling injury of zucchini squash. J. Plant Growth Regulat. 10:101-105.

Wang, C.Y. and J.E. Baker. 1979. Effects of two free radical scavengers and intermittent warming on chilling injury and polar lipid composition of cucumber and sweet pepper fruits. Plant Cell Physiol. 20:243-251.

\title{
Response of Tropical Horticultural Commodities to Insect Disinfestation Treatments
}

\author{
Robert E. Paull \\ Department of Plant Molecular Physiology, College of Tropical Agriculture and Human Resources, University of \\ Hawaii at Manoa, 3190 Maile Way, Honolulu, Hawaii, 96822
}

Postharvest treatments are required to disinfest fresh fruits, vegetables, and flowers of economically important quarantined insects. The damage caused by such insects includes small surface blemishes, destruction of the edible flesh, fruit drop, and spoilage from decay organisms entering the fruit at the site of insect activity (Hagen et al., 1981). These insect pests are of quarantine importance because they are absent from the importing country or region, or the importing country has a "zero tolerance" for all live insects regardless of their economic importance (Armstrong and Couey, 1989). Monitoring insect populations and having regulatory personnel inspect commodities are required to ensure that quarantine treatment protocol and regulations are carried out properly, including proper handling to preclude reinfestation after treatment. Failure to apply disinfestation protocols correctly can result in expensive quarantine and eradication procedures, product losses due to infestation, and costly new quarantine treatments due to introduction of a new pest (Armstrong, 1992). Recent outbreaks of Mediterranean fruit flies in California atest to these failures.

Expansion of world trade in fresh horticultural products has compounded problems associated with regulating quarantine treatments.
The expansion of international passenger traffic and short transit times has meant repeated violations of quarantine barriers. The greatest risk may be associated with contraband fruit smuggled by airline passengers rather than commercial fruit shipments. For example, a 1-week inspection "blitz" during May 1990 of all passenger baggage coming through Los Angeles International Airport from selected Central and South American countries resulted in 677 interceptions of contraband fruit. The total weight seized was almost $1 \mathrm{t}$ and contained 61 fruit fly larvae. This contrasts with the average interception rate of 434 contraband fruit per week with random baggage inspections of all international arrivals.

The reproduction rate, short life cycle, and adaptability of pest insects, as well as their destructive potential, underscore the need for quarantine treatments and regulatory and physical barriers (Carey and Dowell, 1989; Mitchell and Saul, 1990). The reproduction rates for many insects of quarantine importance are rapid, especially under optimum conditions, including moderate to high temperatures and the absence of low winter temperatures (Fletcher, 1987). The time required for life cycle completion differs with environmental factors and species. Development times are similar for all fruit fly species: egg, 1- 
2 days; larvae, 7-9 days; pupae, 10-11 days at 25C (Fletcher, 1987). Oriental fruit flies (Dacus dorsalis Hendel) can have three to 18 generations per year (Saeki et al., 1980; Vargas et al., 1984), depending on temperature (O'Loughlin et al., 1984). This time can be modified by moisture content, ripeness of fruit and degree of larvae crowding (Couey et al., 1985; Ibrahim and Rahman, 1982; Vargas et al., 1983). Most adults have long life spans (50-93 days) and high fecundity (800 to 1600 eggs/female) (Vargas et al., 1984).

Insect host status clearly depends on stage of host development, i.e., stage of fruit ripeness, and cultivar (Greany, 1989). Green fruit normally are not hosts. Fruit flies apparently do not infest maturegreen 'Brazilian', 'Valery', and 'William's' bananas (Musa spp., AAA group) and 'Sharwil' avocados (Persea americana Mill.) (Armstrong, 1983; Armstrong et al., 1983), although these fruits are fruit fly hosts when ripe. At commercial maturity, 'Eureka' and 'Lisbon' lemons [Citrus limon (L.) Burm.f] are not hosts for the Mediterranean fruit fly (Ceratitis capitata Weideman) (Spitler et al., 1984); and papaya (Carica papaya L.) with $<25 \%$ skin yellowing are not preferred fruit fly hosts (Seo et al., 1982). Pineapples [Ananas comosus (L.) Merr.] having at least 50\% 'Smooth Cayenne' parentage are not fruit fly hosts (Armstrong and Vargas, 1982; Armstrong et al., 1979; Seo et al., 1973).

Increased restrictions on the use of postharvest fungicides means that safe postharvest disease control treatments need to be developed. Heat treatments have been the method of choice (Couey, 1989). Until 1984, ethylene dibromide was the fumigant of choice, with methyl bromide used for some commodities. Ethylene dibromide was banned in 1984, and methyl bromide's use is seriously threatened. This review will focus on the physiological response of horticultural products to alternative physical insect disinfestation treatments.

\section{QUARANTINE TREATMENTS AND PLANT RESPONSES}

\section{Irradiation}

There is some uncertainty regarding the irradiation dose required to satisfy insect quarantine requirements. Dose levels of 200 to $300 \mathrm{~Gy}$ have been proposed for fruit fly sterilization (Balock et al., 1966; Seo et al., 1973), 74 to $101 \mathrm{~Gy}$ for Australian fruit flies (Heather et al., 1991), and 50 Gy for codling moth (Cydia pomonella Linne) (Toba and Burditt, 1992). Horticultural responses of few fruit have been studied at these dose levels. Limited data is available on disinfestation of flowers using gamma irradiation (Goodwin and Wellham, 1990; Wit, 1986). This lack of information is due in part to the apparent greater sensitivity of the tissue (unpublished data) and the possible wide spectrum of insects involved.

Gamma irradiation was initially studied in the 1960s and recommended for extending the shelf life of fresh fruit, including papaya (Akamine and Moy, 1983). A semicommercial irradiator also operated in Hawaii during the late 1960s (Dollar et al., 1971). However, the availability of less expensive alternative technologies, such as fumigation, made irradiation uneconomical (Maxie et al., 1971). Irradiation has potential, however, as an insect quarantine procedure (Sommer and Mitchell, 1986), and irradiation $\leq 1.0 \mathrm{kGy}$ was approved for use in the United States (U.S. Food and Drug Administration, 1986). There are consumer concerns regarding the use of irradiation on food products (Schultz et al., 1989); however, a commercial irradiator (Vindicator, Mulberry, Fla.) is operating in Florida.

Fruit responses to irradiation can vary widely. Papaya can tolerate up to $1 \mathrm{kGy} \gamma$-radiation before surface scald occurs, surface color development is not disrupted by up to $2 \mathrm{kGy}$, flavor and aroma $4 \mathrm{kGy}$, and tissue breakdown 5 kGy (Akamine and Moy, 1983; Akamine and Wong, 1966). A 0.75-kGy dose was considered optimum for retaining fruit firmness in papaya, with only slight control of storage decay (Akamine and Wong, 1966). Papaya respiratory activity immediately after irradiation is initially elevated, but returns to the level of nontreated controls within $24 \mathrm{~h}$ (Akamine and Goo, 1971). A delay in climacteric peak and, hence, ripening occurred only in fruit with $<25 \%$ surface color at time of treatment (Akamine and Goo, 1977a, 1977b).

Irradiated papaya ripen more uniformly as a cohort than nonirradiated fruit. Fruit placed immediately into storage at $10 \mathrm{C}$ after irradiation and having $<25 \%$ yellow developed skin scald. Delaying storage by 6 to $12 \mathrm{~h}$ after treatment prevents skin scald (unpublished data). Irradiation slightly retarded softening in papaya fruit during fruit ripening. Premature softening of papaya flesh occasionally occurs in fruit that had $15 \%$ to $35 \%$ yellowing when irradiated. Preharvest conditions that predispose fruit to more rapid fruit softening following irradiation are known but not understood.

\section{Heat}

Heat treatments offer a viable alternative to other quarantine treatment technologies. Heat treatments also can provide disease control (Couey, 1989), are easy to apply, and leave no residues. The disadvantages are the potential for fruit damage, individual commodity variability in response, and higher application cost compared to fumigation. Some heat treatments can improve fruit quality (Klein and Lurie, 1991; Lurie and Klein, 1992). Insect responses to heat treatment and thermal death relationships are better understood than commodity responses (Jang, 1986, 1991; Moss and Jang, 1991; Yokoyama et al., 1991). Mortality due to heat depends on $\mathrm{O}_{2}$ availability, $\mathrm{pH}$, previous temperatures, general energy status of the insects, and insect age and stage (Jang, 1991; Moss and Jang, 1991).

Hot-water immersion treatments have been developed to disinfest Mediterranean fruit fly, melon fly (Dacus cucurbitae Coq.), and oriental fruit fly from bananas (Armstrong, 1982) and papayas (Couey and Hayes, 1986; Hayes et al., 1984) in Hawaii; Caribbean fruit fly (Anastrepha suspensa) in guava (Psidium guajava L.) (Gould and Sharp, 1992); and Caribbean fruit fly, Mexican fruit fly (Anastrepha ludens Loew.), and West Indian fruit fly (Anastrepha obliqua Macquart) from Florida, Mexican, Haitian, or Peruvian mangos (Mangifera indica L.) (Animal and Plant Health Inspection Service, 1987; Sharp, 1986, 1989; Sharp and Picho-Martinez, 1990; Sharp and Spalding, 1984; Sharp et al., 1989b). Possible heat treatments are being considered for codling moth (Yokoyama et al., 1991), oriental fruit moth (Grapholitha molesta Busck) (Yokoyama and Miller, 1987), and Caribbean fruit fly in stone fruit (Sharp, 1990), carambola (Averrhoa carambola L.) (Hallman and Sharp, 1990), and flowers (Hansen et al., 1992). A 20-min, 49C water-bath dip (Akamine and Arisumi, 1953) has been used widely for effective control of some postharvest diseases of papaya. Similar heat treatments have been tested to control disease in other fruit with varying success (Couey, 1989).

Vapor heat was first used in the United States to kill Mediterranean and Mexican fruit flies (Baker, 1952; Hawkins, 1932). Easy-to-use and inexpensive chemical fumigants [ethylene dibromide (EDB) and methyl bromide] for quarantine meant interest in vapor heat faded with their introduction. Research was conducted to develop vapor heat treatments for bell pepper (Capsicum annuum L.), chinese peas (Pisum sativum L.), cucumber (Cucumis sativus L.), eggplant (Solanum melongena L.), green beans (Phaseolus vulgaris L.), lima beans (Phaseolus lunatus L.), litchi (Litchichinensis Sonn.), mango, papaya, tomato (Lycopersicon esculentum Mill.), and yellow wax beans (Phaseolus vulgaris L.) (Balock and Kozuma, 1954; Balock and Starr, 1946; Jones, 1940b; Seo et al., 1974). Commercial vapor heat facilities for many tropical commodities, especially papaya, were built in the United States after 1984, when EDB fumigation was banned. Commercial facilities operate in Okinawa, Philippines, and Thailand.

A high-temperature, forced-air quarantine treatment to kill Mediterranean fruit fly, melon fly, and oriental fruit fly on papaya has been developed (Armstrong et al., 1989; Hansen et al., 1989). This treatment is similar to the vapor heat treatment without the saturated vapor, and is equally as effective.

Heat effects on plant cells. The effect of heat stress on plant cell physiology has been reviewed recently (Alexandrov, 1977; Berry and Bjorkman, 1980; Blum, 1987; Lange et al., 1981; Levitt, 1980; Paull, 1990b). Heat damage is similar in most cells, and in extreme cases, leads to the death of cells, tissues, organs, or the whole plant.

Transferring plants from an ambient to an elevated temperature produces stress. The severity of stress is determined by the temperature differential and duration of exposure. Other factors, such as rapidity of the change in temperature and the previous growing conditions, are also important (Levitt, 1980; Paull, 1990b). The effect of exposure 
time, although recognized by many (Alexandrov, 1977; Blum, 1987; Levitt, 1980; Paull, 1990b), has not been fully investigated and its implications are unclear. A short exposure to near-lethal temperature, such as in insect disinfestation, is a "crisis" situation that relates to survival and the capacity to recover, while longer exposures to less extreme temperatures are more difficult to quantify. Excessive exposure leads to death of plant tissue, and high temperatures can only be tolerated for short periods (Paull, 1990b).

Cellular membranes have been stressed with heat (Alexandrov, 1977). Levitt (1980), in his work on chilling, suggested the use of the term "phase transition." The meaning of this term is unclear, although Levitt (1980) claims cell death occurs at the point of lipid "liquification." Much of the chilling-related work on lipids has been on bulk cellular extracts, and its relevance in vivo has been questioned (Blum, 1987). The loss of cellular membrane integrity with increasing temperature is gradual, with repair and reversibility possible up to the point where a lethal cell temperature is reached.

The role of the membrane in cell death induced by heat has been reviewed (Blum, 1987; Lange et al., 1981) and many hypotheses have been proposed to explain heat injury (Crisan, 1973; Levitt, 1980). Most involve protein denaturation or protein synthesis disruption. Denaturation at lethal temperatures is regarded as nonreversible, while lower temperatures can lead to a reversible inactivation. Heat effects on proteins and enzymes also were reviewed (Alexandrov, 1977; Bernstam, 1978; Brandts, 1967). Lower than lethal temperatures can lead to disruption of transcription and translation steps in protein synthesis (Bernstam, 1978) and possibly protein secretion. Single amino acid substitutions in a protein can significantly alter its thermal stability (Matthews et al., 1980).

Heat shock response. Bacteria, plants, and animals exposed to high temperatures (38-42C) for a brief period acquire transient thermotolerance in the heat shock (HS) response (Burdon, 1988; Chen et al., 1982; Cooper et al., 1984; Kanabus et al., 1984; Key et al., 1981, 1985; Lindquist and Craig, 1988; Yarwood, 1961). As thermotolerance develops, a unique group of proteins is synthesized. These proteins are produced within $30 \mathrm{~min}$ after exposure to temperatures between 34 to 42C (Kanabus et al., 1984) and are called heat-shock proteins (HSP). Thermotolerance and associated HSP have been reported for fieldgrown cotton (Gossypium hirsutum L.) (Burke et al., 1985) and soybean [Glycine $\max$ (L.) Merr.] leaves (Kimpel and Key, 1985), sorghum [Sorghum bicolor (L.) Moench] (Ougham and Stoddart, 1986), and papaya fruit (Paull and Chen, 1990). This phenomenon confers a temporary, acquired heat resistance to sublethal temperatures (Altschuler and Mascarenhas, 1982). There appears to be a fundamental but unclear role for these HSP in cellular function during high-temperature stress (Johnson and Kucay, 1988; Yost and Lindquist, 1988). Tolerance acquired by sudden HS differs from tolerance acquired by sustained growth at a moderately high temperature. Apparently, there is a different mechanism of tolerance induced by the two treatments (Wu and Wallner, 1984). This is supported by HSP being produced at higher temperatures when the temperature is raised slowly (3C/h) vs. more rapidly (Altschuler and Mascarenhas, 1982), thus emphasizing the importance of the HS profile.

Physiological and biochemical evidence exists for HS response in ripening fruit (Klein and Lurie, 1990; Paull and Chen, 1990). Exposing ripening papaya fruit to either $42 \mathrm{C}$ for $4 \mathrm{~h}$ or to 38 to $42 \mathrm{C}$ for $1 \mathrm{~h}$ followed by $3 \mathrm{~h}$ at $22 \mathrm{C}$ results in thermotolerance to the otherwise injurious heat treatment of 49C for $70 \mathrm{~min}$ (Paull and Chen, 1990). Polypeptides with molecular weights similar to those of HSP are translated on extracted polysomal RNA following the $42 \mathrm{C}$ treatment. The levels of all these polypeptides peaked $2 \mathrm{~h}$ after heat treatment and declined within $24 \mathrm{~h}$. The amount of these polypeptides in the nonheated control varied with season of fruit harvest.

Fruit ripening and heat treatments. The lethal temperature for tissue is $45 \mathrm{C}$ for tomatoes, $63 \mathrm{C}$ for grapes (Vitis vinifera $\mathrm{L}$.), and 49 to 52C for apples [Malus domestica (L.) Borkh.] (Huber, 1935). Even below such nonpermissive temperatures, growth and metabolism can be adversely affected by heat. For example, avocado fruit stored at 30 and $34 \mathrm{C}$ ripened abnormally and showed considerable surface pitting, and poor flavor. Ethylene treatment increases the threshold temperature for injury in this fruit (Lee and Young, 1984). Tomato fruit held for more than $6 \mathrm{~h}$ at $>41 \mathrm{C}$ show delayed ripening (Hall, 1964a, 1964b) and increased electrolyte leakage (Inaba and Crandall, 1988). Treatment at $49 \mathrm{C}$ for $20 \mathrm{~min}$ is near the limit for heat tolerance in papaya (Akamine, 1960; Hayes et al., 1984; Paull, 1990b). Papaya ripen poorly above 30C (An and Paull, 1990). Couey (1989) grouped fruit as heat-tolerant or heat-sensitive to hot-water treatment. The heattolerant fruit were bananas, papaya, mangos, pears [Prunus communis (L.) Batsch], and litchis, while the heat-sensitive fruit were peaches [Prunus persica (L.) Batsch], raspberries (Rubus idaeus L.), bell peppers, and muskmelons (Cucumis melo L.). Thermotolerance can vary with cultivar, fruit size, maturity, and postharvest handling (Claypool and Vines, 1956; Jones, 1942; Paull, 1990b; Paull and Chen, 1990; Sinclair and Lindgren, 1955; Sharp et al., 1989a).

Exposing pears (Maxie et al., 1974), tomatoes (Biggs et al., 1988; Ogura et al., 1976; Picton and Grierson, 1988; Yoshida et al., 1984), and papaya (An and Paull, 1990) to temperatures $>30 \mathrm{C}$ for $\geq 48 \mathrm{~h}$ disrupted ripening. This disruption is characterized by a failure to develop normal pigmentation, abnormal softening, and a marked decline in ethylene production (Biggs et al., 1988; Maxie et al., 1974; Paull and Chen, 1990; Picton and Grierson, 1988; Yoshida et al., 1984). Soluble solids concentration is not affected by heat treatment, while titratable acidity declines in apples (Klein and Lurie, 1990; Liu, 1978; Porritt and Lidster, 1978); both are unaffected in grapefruit (Citrus paradisi Macf.) (Miller and McDonald, 1992).

High temperatures affect respiration rate and ethylene synthesis (Akamine, 1966; An and Paull, 1990; Inaba and Chachin, 1988; Jones, 1940a; Maxie et al., 1974; Ogura et al., 1976; Paull and Chen, 1990). Temperatures $>25 \mathrm{C}$ reduce the extent of the respiratory climacteric in avocado (Biale and Young, 1971), and respiratory rise between the initial preclimacteric level and the climacteric peak was $250 \%$ at $25 \mathrm{C}$ and only $30 \%$ at $30 \mathrm{C}$. Twelve or more days at $\approx 33 \mathrm{C}$ suppress tomato respiration, ethylene synthesis, and fruit softening, and this action is not completely reversed after returning the tomato fruit to ambient temperatures (Cheng et al., 1988; Inaba and Chachin, 1988; Ogura et al., 1976; Yoshida et al., 1984). Ripening inhibition above 30C has been ascribed to disrupted protein action during ethylene synthesis (Maxie et al., 1974; Ogura et al., 1975), disrupted polygalacturonase generation or activation (Chan et al., 1981), and suppressed ripeningrelated mRNA synthesis (Paull and Chen, 1990; Picton and Grierson, 1988).

Ethylene synthesis is reversibly inhibited at higher temperatures (Biale, 1960; Chan, 1991; Field, 1984; Paull and Chen, 1990). Temperatures $>35 \mathrm{C}$ cause endogenous ACC to accumulate in apple tissue (Yu et al., 1980), with accompanying reduced ethylene production. The conversion of ACC to $\mathrm{C}_{2} \mathrm{H}_{4}$ apparently is highly inhibited by heat. A rapid loss $(75 \%)$ of ACC oxidase occurs in papaya and other fruit exposed for short periods to temperatures $>40 \mathrm{C}$ (Chan, 1986a, 1986b, 1991; Dunlap et al., 1990; Klein and Lurie, 1990; Paull and Chen, 1990). The heat inactivation in papaya and cucumber is biphasic (Chan, 1986a, 1986b). ACC oxidase activity fully recovers within 3 days in papaya (Paull and Chen, 1990), apples (Klein and Lurie, 1990), and muskmelon (Dunlap et al., 1990) after removing heat. Fruit exposed to high temperature for long periods quickly recover ethylene synthesis ability (Biggs et al., 1988; Dunlap et al., 1990; Ogura et al., 1976). The loss of ACC oxidase activity due to heat treatment in cucumber fruit can be modified by conditioning for $24 \mathrm{~h}$ at $32.5 \mathrm{C}$ (Chan and Linse, 1989a, 1989b). Recovery of ethylene production may require protein synthesis (Biggs et al., 1988), which suggests lowlevel production of ethylene-related mRNA (Picton and Grierson, 1988), or reactivation of pre-existing proteins.

Heating leaves to 44C leads to loss of chloroplast activity, especially photosystem II electron transport (Berry et al., 1975). Chlorophyll fluorescence has been used to monitor heat stress (Smillie and Gibbons, 1981). Delayed light emission, an associated characteristic, declines in papaya skin with first-order kinetics when fruit are heated between 42 to $48 \mathrm{C}$ (Chan and Forbus, 1988). Heat inactivation is biphasic at higher temperatures (49 to 51C). Color changes associated with ripening in tomato are inhibited at storage temperatures $>30 \mathrm{C}$ (Cheng et al., 1988; Goodwin and Jamikorn, 1952). Above 30C, bananas (Burg, 1962) and papaya (An and Paull, 1990) fail to ripen normally and develop soft and watery pulp. 
Electrolyte leakage from tomato disks is induced by increasing temperatures, although the fruit did not exhibit any visible heat injury (Inaba and Crandall, 1988). Critical exposure times for leakage were $34 \mathrm{~min}$ at $55 \mathrm{C}, 105 \mathrm{~min}$ at $50 \mathrm{C}$, and $166 \mathrm{~min}$ at $45 \mathrm{C}$. Fifty percent higher electrolyte leakage occurred in apple disks held at 38C (Lurie and Klein, 1990) than at ambient temperatures. After transferring disks to 20C, leakage declined within 2 days to control levels. Another factor crucial to interpreting leakage data is the increased leakage rate as fruit ripen (Chan, 1991).

Exposing ripening pear fruit to $40 \mathrm{C}$ led to protein synthesis disruption via a loss of polysomes (Romani and French, 1977). This response is readily reversible and established a close correlation between the protein synthesizing machinery and ripening progression. Apples held at $38 \mathrm{C}$ for 4 days have reduced $\mathrm{S}^{35}$-methionine incorporation into what may have been HSP (Lurie and Klein, 1990). Papaya fruit protein synthesis changes following exposure to $38 \mathrm{C}$ for $2 \mathrm{~h}$; there was no accumulation in the control held at $22 \mathrm{C}$ for $10 \mathrm{~h}$. Translated polysomal RNA confirm that new polypeptides are synthesized following heat shock induction (Paull and Chen, 1990). Thermotolerance decreases with continued exposure of papaya fruit to $42 \mathrm{C}$, suggesting that $42 \mathrm{C}$ is the limit for induction of tolerance. Continued exposure to 42C, though still allowing HS-polypeptide synthesis, also caused damage. These results agree with those for tomato fruit treated for long periods at 35C (Picton and Grierson, 1988). The synthesis of ripeningspecific mRNAs and new enzymes is induced during ripening of tomatoes (Christoffersen et al., 1982; Grierson, 1986; Spiers et al., 1984; Tucker and Grierson, 1982). The elevated temperature treatments may lead to softening inhibition, reduced expression of softening, or both, and other ripening-related mRNAs (Picton and Grierson, 1988).

Thermal injury (46C for 65 to $90 \mathrm{~min}$ ) in papaya results in uneven ripening and hard lumps in the flesh and is correlated with a $90 \%$ decrease in normal polygalacturonase levels with a partial recovery to $25 \%$ of normal after 6 days at 24C (Chan et al., 1981). A similar reduction occurred in tomatoes held for several days at 33C (Ogura et al., 1975). The injury is more severe in riper papaya fruit (one-fourth to one-half ripe). Responses similar to those observed in our laboratory (Paull and Chen, 1990), i.e., heated fruit showing delayed ripening and leaving a 1- to $1.5-\mathrm{cm}$-thick area of hard tissue at the center, had already been noted by Chan et al. (1981). The conclusion from this work is that when polygalacturonase activity or other wall-degrading enzymes are increasing in a particular area of the flesh (Paull and Chen, 1983), and transcription is disrupted by heat or protein denaturation, tissue can lose its capacity to soften. This disruption could occur as ribosomes release mRNAs, which has been documented in pears heated to 40C (Romani and French, 1977). The failure to soften could also be attributable to suppression of mRNA for wall-softening enzymes, as found in tomatoes (Picton and Grierson, 1988). The loss of polygalacturonase mRNA in heated tomatoes is not overcome by exogenous ethylene (Picton and Grierson, 1988). Polygalacturonase activity, however, does return after a 6-day lag when the fruit is returned to 25C (Ogura et al., 1975; Yoshida et al., 1984). A similar reversibility in fruit softening occurred in apples held at 38C for 4 days (Lurie and Klein, 1990) or $12 \mathrm{~h}$ at 46C (Klein and Lurie, 1992). Polygalacturonases show little loss of activity when heated to $45 \mathrm{C}$ in vitro (Chan and Tam, 1982; Tucker et al., 1980); hence, heat denaturation is unlikely to be the cause of reduced polygalacturonase activity.

Between 35 to $60 \mathrm{C}$, considerable $(87 \%)$ purified glucanase activity is lost from tomato fruit (Hinton and Pressey, 1980), also 50\% glucanase activity can be lost by exposure to $50 \mathrm{C}$ for $5 \mathrm{~min}$ (Pressey, 1983). The role of these enzymes in fruit softening is unclear. Pectinesterase activity is suppressed in tomatoes held at 33C (Ogura et al., 1975), and the activity several days after returning fruit to room temperature is only one-third of normal ripening fruit.

Modifying heat response. Many procedures have been empirically developed to reduce the injury caused by heat treatment. Disruption of papaya fruit softening by heat treatment is reduced or prevented by a 4-h pretreatment at $42 \mathrm{C}$ or a 1 -h pretreatment at temperatures higher than $35 \mathrm{C}$ followed by $3 \mathrm{~h}$ at 22C (Paull and Chen, 1990). The 8-h approach time to 44C for the papaya vapor heat treatment (Seo et al., 1974 ) is designed to reduce subsequent injury when the fruit is exposed to $44 \mathrm{C}$ for an additional $8.75 \mathrm{~h}$. The approach time would be expected to provide the conditions necessary to develop HSPs and associated thermotolerance. The same would likely occur in deciduous fruits (Claypool and Vines, 1956). The quick rise to 49C using vapor heat always damaged Valencia oranges [Citrus sinensis (L.) Osbeck] and grapefruit (Sinclair and Lindgren, 1955), but they are tolerant when heated for $8 \mathrm{~h}$ at $43 \mathrm{C}$ before the $49 \mathrm{C}$ treatment. Cucumber can be preconditioned by a $24-\mathrm{h}$ treatment at $32.5 \mathrm{C}$ to tolerate subsequent exposure to hot water at 46C for $50 \mathrm{~min}$ (Chan and Linse, 1989b). Although $32.5 \mathrm{C}$ is lower than the temperature normally used to induce HSPs, the 24-h duration could probably induce HSPs.

The extent of protection against softening disruption depends on season, stage of fruit ripeness at exposure, and pretreatment time and temperature. The seasonal variation could be due to field-induced thermotolerance. Understanding the conditions necessary to induce thermotolerance is essential to optimize heat treatments used for insect disinfestation and disease control.

\section{Cold}

Cold treatments for insect disinfestation theoretically are easy to apply and leave no residue. Cold treatments have been suggested for fruit disinfestation based on the success of refrigeration against Mediterranean fruit fly (Back and Pemberton, 1916). Cold quarantine treatments are used to kill Caribbean fruit fly, Mediterranean fruit fly, and Queensland fruit fly (Dacus tryoni Frogg.) on a wide range of fruits (Animal and Plant Health Inspection Service, 1985; Benschoter, 1984, 1988; Gould and Sharp, 1990; Hill et al., 1988; Rippon and Smith, 1979). Eggs and larval stages of fruit flies are killed below 10C, with at least 10 days required below 2.8C (Burditt and Balock, 1985). The length of these treatments and the commercial difficulties of imposing these treatments during shipment limit the use of cold treatments. Most tropical fruit are damaged by extended storage below 10C (Chen and Paull, 1985; Couey, 1982; Paull, 1990a). For example, mature-green papaya can only withstand 7 days at $1 \mathrm{C}$ (Chen and Paull, 1985). Only temperate fruit and those tropical fruit that can tolerate temperatures $<2 \mathrm{C}$, such as litchi, which can be shipped at 0 to $1.1 \mathrm{C}$ (Chen and Paull, 1985) and carambola (Paull, 1990a; Miller et al., 1991), are candidates for cold treatment.

The postharvest storage life of tropical and subtropical crops gradually increases with decreasing storage temperature only within specific limits. The postharvest storage life of tropical, subtropical, and temperate crops reaches a maximum at $\approx 10$ to $12 \mathrm{C}, 4$ to $7 \mathrm{C}$, and $0 \mathrm{C}$, respectively. Higher temperatures allow continued senescence and ripening with an expected $Q_{10}$ of 2 to 4 . Below the 10 to $12 \mathrm{C}$ or 4 to $7 \mathrm{C}$ thresholds, storage life decreases due to chilling injury (CI), and ripening and senescence are severely restricted (Paull, 1990a). This pattern explains why most storage recommendations for tropical commodities are just in the range where CI occurs. For example, papaya can be stored for $\approx 25$ days at $10 \mathrm{C}$ and still have up to 1 week of life at 20C without developing chilling injury (Chen and Paull, 1985). Commercially, papaya is shipped at 7 to 10C. These storage temperature $\times$ duration relationships are in direct contrast to the increasing storage life found for temperate commodities stored at decreasing temperatures to near 0C (Hardenburg et al., 1986).

The response of plant tissue to CI has frequently been separated into primary and secondary responses. This separation is based on a series of events involving multiple events cascading from the primary event after a certain level of CI. Two distinct possibilities are suggested as the primary event: lipid changes or protein changes. Changes in either lipids or proteins as the primary event in CI are thought to occur instantaneously when the tissue is subjected to chilling temperatures. The lipid hypothesis has received the most attention since it was originally proposed in 1965 (Bishop, 1986; Graham and Patterson, 1982; Lyons, 1973). It gained more support, at least for green tissue, after Murata et al. (1992) demonstrated the ability to genetically engineer altered chilling sensitivity.

CI symptoms generally develop after transfer from chilling to nonchilling temperatures. Symptom development is slow, and the symptoms are similar to those that occur for other stresses and injury. CI symptoms have been described by many authors and are summa- 
rized by Morris (1982). Surface lesions are most common and take the form of pitting (eggplant) (McColloch, 1966), scald (papaya, citrus) (Chen and Paull, 1985; Wardlaw, 1937), and large sunken areas (peppers) (Miller and Risse, 1986). Internal brown discoloration of pulp \{pineapple, taro [Colocasia esculenta (L.) Schott] (Paull and Rohrbach, 1985; Rhee and Iwata, 1982), vascular strands (avocado) (Chaplin and Scott, 1980), and seeds (eggplant, tomato) (Autio and Bramlage, 1986; McColloch, 1966) also is common. Water soaking of tissue coupled with wilting and desiccation [ung choi (Ipomoea aquatica Forsk.)] (Hirata et al., 1987) are common symptoms in leaves. The above visual symptoms frequently occur with dysfunction of several developmental processes. The most commonly reported is a failure of fruit to ripen (banana, mango, papaya) (Chen and Paull, 1985; Hatton et al., 1965; Wardlaw and McGuire, 1931) and accelerated senescence (ung choi) (Hirata et al., 1987). These symptoms often lead to reduced postharvest life and increased susceptibility to decay (Chen and Paull, 1985; Sommer and Mitchell, 1987). The sequence of events leading to visible symptoms after primary sensing of chilling temperatures clearly vary with tissue. Physiological CI symptoms in papaya include increased ethylene production and electrolyte leakage (Chan et al., 1985), and alternaria rot (Sommer and Mitchell, 1987); they occur before the appearance of visible symptoms. At 10C, increased ethylene production occurs after 7 days, electrolyte leakage after 14 days, and visible symptoms after 24 days. The relationship between physiological CI symptoms, ethylene production and electrolyte leakage, and visible CI symptoms in papaya is unknown. Information on the time-temperature response to incipient CI for tropical and subtropical fruit and vegetables is limited (Paull, 1990a), although such information is essential for developing optimum postharvest handling and disinfestation procedures.

Fruit ripeness stage and leaf tissue age at the time of low-temperature storage significantly influence sensitivity to visible CI symptom development. The preclimacteric stage is generally more sensitive than the postclimacteric stage for avocado, papaya, 'Honey Dew' melons (Cucumis melo L.), tomatoes, and mango. The extreme sensitivity of bananas to chilling does not allow a difference to be determined. However, banana fruit in less mature apical hands are less susceptible to CI than the more mature distally borne fruit (Marriott, 1980; Marriott et al., 1979). Avocado (Kosiyachinda and Young, 1976) and papaya (An and Paull, 1990) increase in CI sensitivity up to the climacteric, then sensitivity declines. Conditioning some commodities before cold treatment and intermittent warming can give some increased chilling tolerance (Wang, 1982, 1989). Prestorage heat treatments (38C, 3 days) can also increase chilling tolerance of some fruit (Lurie and Klein, 1992).

\section{Controlled atmospheres}

Controlled atmospheres (CA) (reduced $\mathrm{O}_{2}$, elevated $\mathrm{CO}_{2}$, added $\mathrm{CO}$, or all three) have been evaluated as possible insect control treatments in several studies (Aharoni et al., 1981; Benschoter, 1987; Davis and Jay, 1977; Delate et al., 1990; Gaunce et al., 1981; Klaustermeyer et al., 1977; Lidster et al., 1984; Morgan and Gaunce, 1975; Soderstrom, 1977; Soderstrom and Brandl, 1990; Soderstrom et al., 1990; Yahia et al., 1992). This method is safe only when $\mathrm{O}_{2}$ and $\mathrm{CO}_{2}$ concentrations are used, as it does not employ toxic, flammable compounds and leaves no residue. Most fresh, tropical horticultural crops will not tolerate high $\mathrm{CO}_{2}$ concentrations and $<2 \% \mathrm{O}_{2}$ for the long periods effective in insect control in dry cereals and legumes (Bailey and Banks, 1975; Fleurat-Lessard, 1990). CA combinations may be effective in controlling certain insects, possibly in conjunction with other quarantine treatments (Klag, 1985). Little information is available on the effects of CA on tephritid fruit fly growth, development, and mortality. To my knowledge, there are no approved quarantine treatments using CA to disinfest fruit flies from tropical or temperate fruit.

Holding strawberries (Fragaria $\times$ ananassa Duch.) at $2.5 \mathrm{C}$ for 48 hin high $\mathrm{CO}_{2}$ killed all western flower thrips (Frankliniella occidentalis Pergrande) and reduced fruit decay (Aharoni et al., 1981), but some flavor was lost and juice $\mathrm{pH}$ was higher (Ke et al., 1991a). Caribbean fruit fly eggs and larvae are susceptible to $40 \%$ and $100 \% \mathrm{CO}_{2}$ for 48 h at 10C and 22 to 23C, respectively (Benschoter et al., 1981). Aphids (Myzus persicae Sulzer) and cabbage loopers (Trichoplusia ni Hubner) on lettuce (Lactuca sativa L.) are not significantly affected by $70 \%$ $\mathrm{CO}_{2}$ and $5 \% \mathrm{O}_{2}$ for 7 days at $2.5 \mathrm{C}$ (Klaustermeyer et al., 1977). San Jose scale [Quadraspidiotus perniciosus (Comstock)] on apples is controlled by $90 \% \mathrm{CO}_{2}$ and $1 \% \mathrm{O}_{2}$ for 2 days at $12 \mathrm{C}$ without quality loss (Morgan and Gaunce, 1975). Codling moth larvae in apples are not completely controlled after 132 days at CA levels normally used for this fruit (Glass et al., 1961). The survivors could have been diapausing larvae, as control of nondiapausing larvae is obtained with 13 weeks storage in normal CA (Toba and Moffitt, 1991). Apple maggots (Rhagoletis pomonella Walsh) do not survive beyond 7 days at $0 \mathrm{C}$ in $100 \% \mathrm{~N}$ (Kosittrakun, 1989). Storing sweetpotato [Ipomoea batatas (L.) Lam.] roots at $25 \mathrm{C}, 2 \%$ to $4 \% \mathrm{O}_{2}$, and $60 \% \mathrm{CO}_{2}$ may control adult sweetpotato weevils (Cylas formicarius Fab.) (Delate et al., 1990). This method, however, cannot be applied during curing, but only during postcuring to avoid quality loss (Delate and Brecht, 1989). Dried fruit, such as raisins, can be stored in insecticidal atmospheres of $<0.5 \% \mathrm{O}_{2}$ and $14 \% \mathrm{CO}_{2}$ at 27C (Soderstrom and Brandl, 1984, 1990). Most fresh fruit, including tropical products, cannot withstand insecticidal CA treatments $\left(40 \% \mathrm{CO}_{2}, 0.25 \%\right.$ to $0.5 \% \mathrm{O}_{2}$, or both) without quality loss, especially if coupled with low temperature. Bananas are a possible exception, as they are harvested when mature green and can withstand modified-atmosphere storage (Scott et al., 1971). Valencia orange is a subtropical fruit that can withstand low $\mathrm{O}_{2}$ but not high $\mathrm{CO}_{2}$ (Ke and Kader, 1990).

Apples and pears stored in $\mathrm{N}$ gas at $0 \mathrm{C}$ for 25 days accumulated $\mathrm{CO}_{2}$, had higher pyruvate decarboxylase and alcohol dehydrogenase activities, and increased acetaldehyde and ethanol levels (Ke et al., 1991b; Kosittrakun, 1989). ACC oxidase decreased and aminocyclopropane carboxylic acid concentration increased in the same system. Blueberries (Vaccinium spp.), red raspberries, and blackberries (Rubus ulmifolius L.) could be kept under the same conditions for 9, 7, and 5 days, respectively. Longer periods lead to off-flavor that does dissipate (Kosittrakun, 1989). Nectarines (Prunus persica L.) are probably unable to withstand the low- $\mathrm{O}_{2}(0.5 \%)$ conditions needed to control insects; 6 days at $5 \mathrm{C}$ caused abnormal ripening, suppressed ethylene production, elevated ethanol and acetaldehyde levels, and increased internal browning (Smilanick and Fouse, 1989). Papaya can only be stored in low $\mathrm{O}_{2}(0.4 \%)$ for 3 days at $20 \mathrm{C}$ before developing an off-flavor (Yahia et al., 1992), while mango tolerates up to 5 days (Yahia and Vazquez- Morena, 1993).

\section{Reduced pressure}

Limited information exists that shows this technology may be effective against some pests. Exposing lettuce to $2.66 \mathrm{kPa}$ for $52 \mathrm{~h}$ killed all green peach aphids (Myzus persicae Sulzer) without apparently injuring lettuce (Aharoni et al., 1986).

\section{Washing}

Washing is only effective for surface insects, such as scales, and can only be used on those commodities able to withstand washing. It is used widely in conjunction with insecticidal soaps to disinfest flowers and ornamental cut-leaf materials (Hata et al., 1992).

\section{SUMMARY}

Heat treatments either alone or in combination with other treatments offer the best current alternative for insect disinfestation for tropical and subtropical commodities. The physiological changes that occur during short-term stress are poorly understood. Work is underway to understand these processes and develop approaches to reduce the impact of this stress. However, this work cannot be successfully implemented without understanding how preharvest factors influence a commodity's sensitivity to heat. In addition, the interaction of heat stress and susceptibility to disease is not understood. The optimum method would include heat treatment that achieves insect disinfestation and minimal fungicidal doses to control disease. 


\section{Literature Cited}

Aharoni, Y., A. Apelbaum, and A. Copel. 1986. Use of reduced atmospheric pressure for control of the green peach aphid on harvested head lettuce. HortScience 21:469-470.

Aharoni, Y., J.K. Stewart, and D.G. Guadagni. 1981. Modified atmospheres to control western flower thrips on harvested strawberries. J. Econ. Entomol. 74:338-340.

Akamine, E.K. 1960. Temperature effects in fresh papayas processed for shipment. Hawaii Agr. Expt. Sta. Bul. 122.

Akamine, E.K. 1966. Respiration of fruits of papaya (Carica papaya L., var. Solo) with reference to the effect of quarantine disinfestation treatments. Proc. Amer. Soc. Hort. Sci. 89:231-236.

Akamine, E.K. and T. Arisumi. 1953. Control of postharvest storage decay of fruits of papaya (Carica papaya L.) with special reference to the effect of hot water. Proc. Amer. Soc. Hort. Sci. 61:270-274.

Akamine, E.K. and T. Goo. 1971. Respiration of gamma irradiated fresh fruit. J. Food Sci. 36:1074-1077.

Akamine, E.K. and T. Goo. 1977a. Respiration, ethylene production, and shelf life extension in irradiated papaya fruit after storage under simulated shipping condition. Hawaii Agr. Expt. Sta. Tech. Bul. 93. p. 12.

Akamine, E.K. and T. Goo. 1977b. Effects of gamma irradiation on shelf life extension of fresh papayas (Carica papaya L. var. Solo). Hawaii Agr. Expt. Sta. Res. Bul. 165. p. 23.

Akamine, E.K. and J.H. Moy. 1983. Delay in postharvest ripening and senescence of fruits, p. 129-158. In: E.S. Josephson and M.S. Peterson (eds.). Preservation of food by ionizing radiation. vol. III. CRC Press, Boca Raton, Fla.

Akamine, E.K. and R.T.F. Wong. 1966. Extending shelf life of papayas with gamma irradiation. Hawaii Farm Sci. 15:4-6.

Alexandrov, V.Ya. 1977. Cells, molecules and temperature (translated from Russian by V.A. Bernstam). Springer-Verlag, Berlin.

Altschuler, M. and J.P. Mascarenhas. 1982. Heat shock proteins and effects of heat shock in plants. Plant Mol. Biol. 1:103-115

An, R.F. and R.E. Paull. 1990. Storage temperature and ethylene on the ripening of papaya fruit. J. Amer. Soc. Hort. Sci. 115:949-953.

Animal and Plant Health Inspection Service. 1985. Section VI-T107. Plant protection and quarantine manual. U.S. Dept. Agr., Hyattsville, Md.

Animal and Plant Health Inspection Service. 1987. Section IV-T102, (c). Plant protection and quarantine treatment manual. U.S. Dept. Agr., Hyattsville, $\mathrm{Md}$

Armstrong, J.W. 1982. Development of a hot-water immersion quarantine treatment for Hawaiian grown 'Brazilian' bananas. J. Econ. Entomol. 75:787-790.

Armstrong, J.W. 1983. Infestation biology of three fruit fly species on 'Brazilian', 'Valery' and 'Williams' cultivars of bananas in Hawaii. J. Econ. Entomol. 76:539-543.

Armstrong, J.W. 1992. An overview of alternative quarantine treatment technologies to methyl bromide fumigation for agricultural commodities. 19th Intl. Entomol. Congr., Beijing, China, 28 June-4 July 1992. (Abstr.)

Armstrong, J.W. and H.M. Couey. 1989. Fruit disinfestation 9.9.1 Fumigation heat and cold, p. 411-424. In: A.S. Robinson and G. Hooper (eds.). World crop pests. vol. 3B. Elsevier, Amsterdam.

Armstrong, J.W., J.D. Hansen, B.K.S. Hu, and S.A. Brown. 1989. Hightemperature, forced air quarantine treatment for papaya infested with Tephritid fruit flies (Diptera: Tephritidae). J. Econ. Entomol. 82:16671674

Armstrong, J.W., W.C. Mitchell, and G.J. Farias. 1983. Resistance of 'Sharwil' avocados at harvest maturity to infestation by three fruit fly species in Hawaii. J. Econ. Entomol. 76:119-121.

Armstrong, J.W. and R.I. Vargas. 1982. Resistance of pineapple variety '59656 ' to field populations of oriental fruit flies and melon flies. J. Econ. Entomol. 75:781-782.

Armstrong, J.W., J.D. Vriesenga, and C.Y.L. Lee. 1979. Resistance of pineapple varieties 'D-10' and 'D-20' to field populations of oriental fruit flies and melon flies. J. Econ. Entomol. 72:6-7.

Autio, W.R. and W.J. Bramlage. 1986. Chilling sensitivity of tomato fruit in relation to ripening and senescence. J. Amer. Soc. Hort. Sci. 111:201.

Back, E.A. and C.E. Pemberton. 1916. Effect of cold-storage temperatures upon the Mediterranean fruit fly. J. Agr. Res. 5:657-666.

Bailey, S.W. and H.J. Banks. 1975. The use of controlled atmospheres for storage of grain, p. 362-374. In: Intl. Working Conf. Stored-Product Entomol., 1974, Savannah, Ga.

Baker, A.C. 1952. The vapor-heat process. U.S. Dept. Agr. Yrbk. U.S. Government Printing Office, Washington, D.C.

Balock, J.W., A.K. Burditt, S.T. Seo, and E.K. Akamine. 1966. Gamma irradiation as a quarantine treatment for Hawaiian fruit flies. J. Agr. Entomol. 59:202-204.

Balock, J.W. and T. Kozuma. 1954. Sterilization of papaya by means of vapor- heat quick run-up. Special Rpt. 7, Fruit Fly Investigations in Hawaii. U.S. Dept. Agr., Entomol. Res. Branch, Honolulu.

Balock, J.W. and D.F. Starr. 1946. Mortality of the Mexican fruitfly in mangoes treated by the vapor-heat process. J. Econ. Entomol. 38:646-651.

Benschoter, C.A. 1984. Low-temperature storage as a quarantine treatment for the Caribbean fruit fly (Diptera: Tephritidae) in Florida citrus. J. Econ. Entomol. 77:1233-1235.

Benschoter, C.A. 1987. Effects of modified atmospheres and refrigeration temperatures on survival of eggs and larvae of the Caribbean fruit fly (Diptera: Tephritidae) in laboratory diet. J. Econ. Entomol. 80:1223-1225.

Benschoter, C.A. 1988. Methyl bromide fumigation and cold storage as treatments for California stone fruits and pears infested with the Caribbean fruit fly (Diptera: Tephritidae). J. Econ. Entomol. 81:1665-1667.

Benschoter, C.A., D.H. Spalding, and W.F. Reeder. 1981. Toxicity of atmospheric gases to immature stages of Anastrapha suspensa. Fla. Entomologist 64:543-544.

Bernstam, V.A. 1978. Heat effects on protein biosynthesis. Annu. Rev. Plant Physiol. 29:25-46.

Berry, J. and O. Bjorkman. 1980. Photosynthetic response and adaptation to temperature in higher plants. Annu. Rev. Plant Physiol. 31:491-543.

Berry, J.A., D.C. Fork, and S. Garrison. 1975. Mechanistic studies of thermal damage to leaves. Carnegie Inst. Washington Yrbk. 74:751-759.

Biale, J.B. 1960. Respiration of fruits, p. 536-592. In: W. Ruhland (ed.). Handbuch der Pflanzenphysiologie. Springer-Verlag, Berlin.

Biale, J.B. and R.E. Young. 1971. The avocado pear, p. 1-63. In: A.C. Hulme (ed.). The biochemistry of fruits and their products. Academic, New York.

Biggs, M.S., W.R. Woodson, and A.K. Handa. 1988. Biochemical basis of high temperature inhibition of ethylene biosynthesis in ripening tomato fruit. Physiol. Plant. 72:572-578.

Blum, A. 1987. Plant breeding for stress environments. CRC Press, Boca Raton, Fla.

Brandts, J.F. 1967. Heat effects on proteins and enzymes, p. 25-72. In: A.H. Rose (ed.). Thermobiology. Academic, New York.

Burditt, A.K. and J.W. Balock. 1985. Refrigeration as a quarantine treatment for fruits and vegetables infested with eggs and larvae of Dacus dorsalis and Dacus cucurbitae (Diptera: Tephritidae). J. Econ. Entomol. 78:885-887.

Burdon, R.H. 1988. The heat shock proteins. Endeavour 12:133-138.

Burg, S.P. 1962. The physiology of ethylene formation. Annu. Rev. Plant Physiol. 13:265-302.

Burke, J.J., J.L. Hatfield, R.R. Klein, and J.E. Mullet. 1985. Accumulation of heat shock proteins in field grown cotton. Plant Physiol. 78:394-398.

Carey, J.R. and R.V. Dowell. 1989. Exotic fruit fly pests and California agriculture. Calif. Agr. 43(3):38-40.

Chan, H.T. 1986a. Effects of heat treatments on the ethylene-forming enzyme system in papaya. J. Food Sci. 51:581-583.

Chan, H.T. 1986b. Heat inactivation of the ethylene forming enzyme system in cucumber. J. Food Sci. 51:1491-1493.

Chan, H.T. 1991. Ripeness and tissue depth effects on heat inactivation of papaya ethylene-forming enzyme. J. Food Sci. 56:996-998.

Chan, H.T. and W.B. Forbus. 1988. Delayed light emission as a biochemical indicator of papaya heat treatment. J. Food Sci. 53:1490-1492.

Chan, H.T. and E. Linse. 1989a. Conditioning cucumbers to increase heat resistance in EFE system. J. Food Sci. 54:1375-1376.

Chan, H.T. and E. Linse. 1989b. Conditioning cucumbers for quarantine heat treatments. HortScience 24:985-989.

Chan, H.T., S. Sanxter, and H.M. Couey. 1985. Electrolyte leakage and ethylene production induces by chilling injury of papayas. HortScience 20:1070-1072.

Chan, H.T., Jr., and S.Y.T. Tam. 1982. Partial separation and characterization of papaya endo- and exo-polygalacturonase. J. Food Sci. 47:1478-1483.

Chan, H.T., Jr., S.Y.T. Tam, and S.T. Seo. 1981. Papaya polygalacturonase and its role in thermally injured ripening fruit. J. Food Sci. 46:190-197.

Chaplin, G.R. and K.J. Scott. 1980. Association of calcium in chilling injury susceptibility of stored avocado. HortScience 15:514.

Chen, H.H., Z.Y. Shen, and P.H. Li. 1982. Adaptability of crop plants to high temperature stress. Crop Sci. 22:719-725.

Chen, N.M. and R.E. Paull. 1985. Development and prevention of chilling injury in papaya fruit. J. Amer. Soc. Hort. Sci. 111:639-643.

Cheng, T.S., J.D. Floros, R.L. Shewfelt, and C.J. Chang. 1988. The effect of high temperature stress on ripening of tomatoes (Lycopersicon esculentum). J. Plant Physiol. 132:459-464.

Christoffersen, R.E., E. Warm, and G.E. Laties. 1982. Gene expression during fruit ripening in avocado. Planta 155:52-57.

Claypool, L.L. and H.M. Vines. 1956. Commodity tolerance studies of deciduous fruits to moist heat and fumigants. Hilgardia 24:297-355.

Cooper, P., T-H.D. Ho, and R.M. Hauptmann. 1984. Tissue specificity of the heat-shock response in maize. Plant Physiol. 75:431-441.

Couey, H.M. 1982. Chilling injury of crops of tropical and subtropical origin. HortScience 17:162-165. 
Couey, H.M. 1989. Heat treatment for control of postharvest disease and insect pests of fruit. HortScience 24:198-202.

Couey, H.M., J.W. Armstrong, J.W. Hylin, W. Thornburg, A.N. Nakamura, E.S. Linse, J. Ogata, and R. Vetro. 1985. Quarantine procedure for Hawaiian papaya using a hot-water treatment and high-temperature, low-dose ethylene dibromide fumigation. J. Econ. Entomol. 78:879-884.

Couey, H.M. and C.F. Hayes. 1986. Quarantine procedure for Hawaiian papaya using fruit selection and a two-stage hot-water immersion. J. Econ. Entomol. 79:1307-1314.

Crisan, E.V. 1973. Current concepts of thermophilism and the thermophilic fungi. Mycologia 65:1171-1198.

Davis, R. and E.G. Jay. 1977. The current status of controlled atmospheres as a method of insect control, p. 207-211. In. D.H. Dewey (ed.). Hort. Rpt. 28, Michigan State Univ., East Lansing.

Delate, K.M. and J.K. Brecht. 1989. Quality of tropical sweet potatoes exposed to controlled atmosphere treatments for postharvest insect control. J. Amer. Soc. Hort. Sci. 114:963-968.

Delate, K.M., J.K. Brecht, and J.A. Coffelt. 1990. Controlled atmosphere treatments for control of sweet potato weevil (Coleoptera: Airculionidae) in stored tropical sweet potatoes. J. Econ. Entomol. 83:461-465.

Dollar, A.M., M. Hanaoka, G.A. McClish, and J.H. Moy. 1971. Semi commercial scale studies on irradiated papaya, p. 137-156. In: Disinfestation of fruit by irradiation. Proc. Use Irradiation to Solve Quarantine Problems International Fruit Trade. Intl. Atomic Energy Agency PL422/14.

Dunlap, J.R., S.E. Lingle, and G.E. Lester. 1990. Ethylene production in netted muskmelon subjected to postharvest heating and refrigerated storage. HortScience 25:207-209.

Field, R.J. 1984. The effect of temperature on ethylene production by plant tissue, p. 47-69. In: J.A. Roberts and G.A. Tucker (eds.). Ethylene and plant development. Butterworths, London.

Fletcher, B.S. 1987. The biology of dacine fruit flies. Annu. Rev. Entomol. $32: 115-144$.

Fleurat-Lessard, F. 1990. Effect of modified atmospheres on insects and mites infesting stored products, p. 21-38. In: M. Calderon and R. Barkai-Golan (eds.). Food preservation by modified atmospheres. CRC Press, Boca Raton, Fla.

Gaunce, A., C.V.G. Morgan, and M. Meheriuk. 1981. Control of tree fruit insects with modified atmospheres, p. 383-390. In: D.G. Richardson and M. Meheriuk (ed.). Proc. 3rd Controlled Atmospheres Res. Conf., Oregon State Univ., Corvallis.

Glass, E.H., P.J. Chapman, and R.M. Smock. 1961. Fate of apple maggot and plum curculis larvae in apple fruit held in controlled atmosphere storage. J. Econ. Entomol. 54:915-918.

Goodwin, S. and T.M. Wellham. 1990. Gamma irradiation for disinfestation of cut flowers infested by two spotted spider mite (Acarina: Tetranychidae). J. Econ. Entomol. 83:1455-1458.

Goodwin, T.W. and M. Jamikorn. 1952. Biosynthesis of carotenes in ripening tomatoes. Nature 170:104-105.

Gould, W.P. and J.L. Sharp. 1990. Cold-storage quarantine treatment for carambolas infested with the Caribbean fruit fly (Diptera: Tephritidae). J. Econ. Entomol. 83:458-460.

Gould, W.P. and J.L. Sharp. 1992. Hot water immersion quarantine treatment for guava infested with Caribbean fruit fly (Diptera: Tephritidae) J. Econ. Entomol. 85:1235-1239.

Graham, D. and B.D. Patterson. 1982. Responses of plants to low nonfreezing temperatures: Proteins, metabolism, and acclimation. Annu. Rev. Plant Physiol. 33:347.

Greany, P.D. 1989. Host plant resistance to Tephritids: An underexploited control strategy, p. 353-362. In: A.S. Robinson and G. Hooper (eds.). Fruit flies Their biology, natural enemies and control. Elsevier, Amsterdam.

Grierson, D. 1986. Molecular biology of fruit ripening, p. 363-383. In: B.J. Miflin (ed.). Plant molecular and cell biology. Oxford Univ. Press, Oxford, England.

Hagen, K.S., W.A. Allen, and R.L. Tassan. 1981. Mediterranean fruit fly: The worst may be yet to come. Calif. Agr. 35(3-4):5-7.

Hall, C.B. 1964a. The ripening response of detached tomato fruits to daily exposures to high temperatures. Proc. Fla. State Hort. Soc. 76:252-256.

Hall, C.B. 1964b. The effect of short periods of high temperature on the ripening of detached tomato fruits. Proc. Amer. Soc. Hort. Sci. 84:501-506.

Hallman, G.J. and J.L. Sharp. 1990. Hot-water immersion quarantine treatment for carambolas infested with Caribbean fruit fly (Diptera: Tephritidae). J. Econ. Entomol. 83:1471-1474.

Hansen, J.D., J.W. Armstrong, B.K.S. Hu, and S.A. Brown. 1989. Thermal death of third instars of Oriental fruit flies (Diptera: Tephritidae) in developing quarantine treatments for papayas. J. Econ. Entomol. 83:160167.

Hansen, J.D., A.H. Hara, and V.L. Tenbrink. 1992. Vapor heat: A potential treatment to disinfest tropical flowers and foliage. HortScience 27:139143.
Hardenburg, R.E., A.E. Watada, and C.Y. Wang. 1986. The commercial storage of fruits, vegetables, and florist and nursery stocks. U.S. Dept. Agr. Hdbk. 66.

Hata, T.Y., A.H. Hara, E.B. Jang, L.S. Imaino, B.K.S. Hu, and V.L. Tenbrink. 1992. Pest management before harvest and insecticidal dip after harvest as a systems approach to quarantine security for red ginger. J. Econ. Entomol. 85:2310-2316.

Hatton, T.T., W.F. Reeder, and C.W. Campbell. 1965. Ripening and storage of Florida mangos. U.S. Dept. Agr. Mktg. Res. Rpt. 725.

Hawkins, L.A. 1932. Sterilization of citrus fruit by heat. Citriculture 9(78):21-22.

Hayes, C.F., H.T.G. Chingon, F.A. Nitta, and W.J. Wang. 1984. Temperature control as an alternative to ethylene dibromide fumigation for the control of fruit flies (Diptera: Tephritidae) in papaya. J. Econ. Entomol.77:683686.

Heather, N.W., R.J. Corcoran, and C. Banos. 1991. Disinfestation of mangoes with gamma irradiation against two Australian fruit flies (Diptera: Tephritidae). J. Econ. Entomol. 84:1304-1307.

Hill, A.R., C.J. Rigney, and A.N. Sproul. 1988. Cold storage of oranges as a disinfestation treatment against the fruit flies Dacus tryoni (Froggatt) and Ceratitis capitata (Wiedemann) (Diptera: Tephritidae). J. Econ. Entomol. 81:257-260.

Hinton, D.M. and R. Pressey. 1980. Glucanases in fruits and vegetables. J. Amer. Soc. Hort. Sci. 105:499-502.

Hirata, K., K. Chachin, and T. Iwata. 1987. Changes of $\mathrm{K}^{+}$leakage, free amino acid contents and phenyl propanoid metabolism in water convolvulus (Ipomoea aquatica Forsk) with reference to chilling injury. J. Jpn. Soc. Hort. Sci. 55:516.

Huber, H. 1935. Der Wärmehaushalt der Pflanzen. Naturwiss. Landwirtsch. $17: 1-148$.

Ibrahim, A.G. and M.D.A. Rahman. 1982. Laboratory studies on the effects of selected tropical fruit on the larvae of Dacus dorsalis Hendel. Peranika 5:90-94.

Inaba, M. and K. Chachin. 1988. Influence of and recovery from hightemperature stress on harvested mature green tomatoes. HortScience 23:190192

Inaba, M. and P.G. Crandall. 1988. Electrolyte leakage as an indicator of high temperature injury to harvested mature green tomatoes. J. Amer. Soc. Hort. Sci. 113:96-99.

Jang, E.B. 1986. Kinetics of thermal death in eggs and first instars of three species of fruit flies (Diptera: Tephritidae). J. Econ. Entomol. 79:700-705.

Jang, E.B. 1991. Thermal death kinetics and heat tolerance in early and late third instar of the Oriental fruit fly (Diptera: Tephritidae). J. Econ. Entomol. 84:1298-1303.

Johnson, R.N. and B.L. Kucay. 1988. Competitive inhibitor of hsp 70 gene expression causes thermosensitivity. Science 242:1551-1554.

Jones, W.W. 1940a. The influence of relative humidity on the respiration of papaya at high temperature. Proc. Amer. Soc. Hort. Sci. 37:119-124.

Jones, W.W. 1940b. Vapour-heat treatment for fruits and vegetables grown in Hawaii. Hawaii Agr. Expt. Sta. Circ. 16.

Jones, W.W. 1942. Respiration and chemical changes of the papaya fruit in relation to temperature. Plant Physiol. 17:481-486.

Kanabus, J., C.S. Pikaad, and J.H. Cherry. 1984. Heat shock proteins in tobacco cell suspension during growth cycle. Plant Physiol. 75:639-644.

Ke, D. and A.A. Kader. 1990. Tolerance of 'Valencia' oranges to controlled atmospheres as determined by physiological responses and quality attributes. J. Amer. Soc. Hort. Sci. 115:779-783.

Ke, D., L. Goldstein, M. O'Mahony, and A.A. Kader. 1991a. Effects of short term exposure to low $\mathrm{O}_{2}$ and high $\mathrm{CO}_{2}$ atmospheres on quality attributes of strawberries. J. Food Sci. 56:50-54.

Ke, D., L. Rodruguez-Sinobas, and A.A. Kader. 1991b. Physiology and prediction of fruit tolerance to low oxygen atmospheres. J. Amer. Soc. Hort. Sci. 116:253-260.

Key, J.L., C.Y. Lin, and T.M. Chen. 1981. Heat shock proteins of higher plants. Proc. Natl. Acad. Sci. USA 78:3526-3530.

Key, J.L., et al. 1985. Physiological and molecular analysis of the heat shock response in plants, p. 327-349. In: B.G. Atkinson and D.B. Walden (eds.). Changes in eukaryotic gene expression in response to environmental stress. Academic, New York.

Kimpel, J.A. and J.L. Key. 1985. Presence of heat shock mRNA's in field grown soybeans. Plant Physiol. 79:672-678.

Klag, N.G. 1985. Use of CA for quarantine control of insects of fresh fruits and vegetables, p. 199-206. In: S. Blankenship (ed.). Controlled atmospheres for storage and transport of perishable agricultural commodities. 4th Natl. Controlled Atmosphere Res. Conf., Raleigh, N.C.

Klaustermeyer, J.A., A.A. Kader, and L.L. Morris. 1977. Effect of controlled atmospheres on insect control in harvested lettuce. In: D.H. Dewey (ed.). Controlled atmospheres for the storage and transport of perishable agricultural commodities. Michigan State Univ. Hort. Rpt. 28:203-204. 
Klein, J.D. and S. Lurie. 1990. Prestorage heat treatment as a means of improving poststorage quality of apples. J. Amer. Soc. Hort. Sci. 115:265269.

Klein, J.D. and S. Lurie. 1991. Postharvest heat treatment and fruit quality. Postharvest News \& Info. 2:15-19.

Klein, J.D. and S. Lurie. 1992. Prestorage heating of apple fruit for enhanced postharvest quality: Interaction of time and temperature. HortScience 27:326-328.

Kosittrakun, M. 1989. Effect of near atmospheric storage conditions on physiology and flavor of various fruit types and on mortality of apple maggot (Rhagoletis pomonella). PhD Diss., Dept. of Horticulture, Oregon State Univ., Corvallis.

Kosiyachinda, S. and R.E. Young. 1976. Chilling sensitivity of avocado at different stages of the respiratory climacteric. J. Amer. Soc. Hort. Sci. 101:665.

Lange, O.L., P.S. Nobel, C.B. Osmond, and H. Ziegler (eds.). 1981. Physiological plant ecology. I. Responses to the physical environment. SpringerVerlag, Berlin.

Lee, S.K. and R.E. Young. 1984. Temperature sensitivity of avocado fruit in relation to $\mathrm{C}_{2} \mathrm{H}_{4}$ treatment. J. Amer. Soc. Hort. Sci. 109:689-692.

Levitt, J. 1980. Responses of plants to environmental stresses. vol. I. 2nd ed. Academic, NewYork.

Lidster, P.D., K.H. Stanford, and K.B. McRae. 1984. Effects of temperature and controlled atmospheres on survival of overwintering populations of European red mite eggs on stored 'McIntosh' apples. HortScience 19:257258.

Lindquist, S. and E.A. Craig. 1988. The heat shock proteins. Annu. Rev. Genetics 22:631-677.

Liu, F.W. 1978. Modification of apple quality by high temperature. J. Amer. Soc. Hort. Sci. 103:730-732.

Lurie, S. and J.D. Klein. 1990. Heat treatment of ripening apples: Differential effects on physiology and biochemistry. Physiol. Plant. 78:181-186.

Lurie, S. and J.D. Klein. 1992. Ripening characteristics of tomatoes stored at 12C and 2C following a prestorage heat treatment. Scientia Hort. 51:55-64.

Lyons, J.M. 1973. Chilling injury in plants. Annu. Rev. Plant Physiol. 24:445466.

Marriott, J. 1980. Bananas physiology and biochemistry of storage and ripening for optimum quality. CRC Crit. Rev. Food Sci. Nutr. 13:41.

Marriott, J., S. New, E.A. Dixon, and K.I. Martin. 1979. Factors affecting the preclimacteric period of banana fruit bunches. Ann. Appl. Biol. 93:91.

Matthews, C.R., M.M. Crisanti, G.L. Gepner, G. Velicelebi, and J.M. Sturtevant. 1980. Effect of single amino acid substitution on the thermal stability of the alpha-subunit of tryptophan synthase. Biochemistry 19:1290-1293.

Maxie, E.C., F.G. Mitchell, N.F. Sommer, R.G. Snyder, and H.L. Rae. 1974. Effects of elevated temperatures on ripening of 'Bartlett' pears Pyrus communis L. J. Amer. Soc. Hort. Sci. 99:344-349.

Maxie, E.C., N.F. Sommer, and F.G. Mitchell. 1971. Infeasibility of irradiating fresh fruit and vegetables. HortScience 6:202-204.

McColloch, L.P. 1966. Chilling injury of eggplant fruits. U.S. Dept. Agr. Mktg. Res. Rpt. 749:5.

Miller, W.R. and R.E. McDonald. 1992. Postharvest quality of early season grapefruit after forced-air vapor heat treatment. HortScience 27:422-424.

Miller, W.R. and L.A. Risse. 1986. Film wrapping to alleviate chilling injury of bell peppers during cold storage. HortScience 21:467.

Miller, W.R., R.E. McDonald, and M. Nisperos-Carriedo. 1991. Quality of 'Arkin' carambolas with or without conditioning followed by low-temperature quarantine treatment. Proc. Fla. State Hort. Soc. 104:118-122.

Mitchell, W.C. and S.H. Saul. 1990. Current control methods for the Mediterranean fruit fly, Ceratitis capitata, and their application in the U.S.A. Rev. Agr. Entomol. 78:923-930.

Morgan, C.V.G. and A.P. Gaunce. 1975. Carbon dioxide as a fumigant against the San Jose scale (Homoptera: Diaspididae) on harvested apples. Can. Entomol. 107:935-936.

Morris, L.L. 1982. Chilling injury of horticultural crops: An overview. HortScience 17:161.

Moss, J. I. and E.B. Jang. 1991. Effects of age and metabolic stress on heat tolerance of Mediterranean fruit fly (Diptera: Tephritidae) eggs. J. Econ. Entomol. 84:537-541.

Ogura, N., R. Hayashi, T. Ogishima, Y. Abe, H. Nakegawa, and H. Takehana. 1976. Ethylene production by tomato fruits at various temperatures and effect of ethylene treatment on fruits. J. Agr. Chem. Soc. Jpn. 50:519-523.

Ogura, N., H. Nakagawa, and H. Takehana. 1975. Effect of storage temperature of tomato fruits on changes of their polygalacturonase and pectinesterase activities accompanied with ripening. J. Agr. Chem. Soc. Jpn. 49:271-274.

O'Loughlin, G.T., R.A. East, and A. Meats. 1984. Survival, development rates and generation times of Queensland fruit fly, Dacus tyroni in a marginally favorable climate: Experiments in Victoria. Austral. J. Zool. 32:353-361.

Ougham, H.J. and J.L. Stoddart. 1986. Synthesis of heat shock proteins and acquisition of thermotolerance in high temperature tolerant and high temperature susceptible lines of sorghum. Plant Sci. 44:163-167.

Paull, R.E. 1990a. Chilling injury in tropical and subtropical crops, p. 17-36. C.Y. Wang (ed.). Chilling injury of horticultural crops. CRC Press, Boca Raton, Fla.

Paull, R.E. 1990b. Postharvest heat treatments and fruit ripening. Postharvest News \& Info. 1:355-363.

Paull, R.E. and N.J. Chen. 1983. Postharvest variation in cell wall-degrading enzymes of papaya (Carica papaya L.) during fruit ripening. Plant Physiol. 72:382-385.

Paull, R.E. and N.J. Chen. 1990. Heat shock response in field grown ripening papaya fruit. J. Amer. Soc. Hort. Sci. 115:623-631.

Paull, R.E. and K.G. Rohrbach. 1985. Symptom development of chilling injury in pineapple fruit. J. Amer. Soc. Hort. Sci. 110:100-105.

Picton, S. and D. Grierson. 1988. Inhibition of expression of tomato-ripening genes at high temperature. Plant, Cell \& Environ. 11:265-272.

Porritt, S. and P. Lidster. 1978. The effect of prestorage heating on ripening and senescence of apples during cold storage. J. Amer. Soc. Hort. Sci. 103:584 587.

Pressey, R. 1983. beta-Galactosidases in ripening tomatoes. Plant Physiol. 71:132-135.

Rhee, J.K. and M. Iwata. 1982. Histological observations on the chilling injury of taro tubers during cold storage. J. Jpn. Soc. Hort. Sci. 51:362-368.

Rippon, L.E. and R.J. Smith. 1979. Postharvest treatment of Chinese gooseberries (kiwifruit) for the control of Queensland fruit fly. Rural News 73:3435

Romani, R. and K. French. 1977. Temperature-dependent changes in the polysomal population of senescent (ripening) pear fruit. Plant Physiol. 60:930-932.

Saeki, S., M. Katayama, and M. Okumura. 1980. Effect of temperature on the development of the oriental fruit fly and its possible destruction in the mainland of Japan. Res. Bul., Plant Protection Serv. Jpn. 16:73-76.

Schultz, H.G., C.M. Bruhn, and K.V. Diaz-Krauf. 1989. Consumer attitude toward irradiated foods: Effects of labeling and benefits information. Food Technol. 43(10):80-86.

Scott, K.J., J.R. Blake, G. Strachan, B.L. Tugwell, and W.B. McGlasson. 1971. Transport of bananas at ambient temperatures using polyethylene bags. Trop. Agr. 48:245-254.

Seo, S.T., G.J. Farias, and E.J. Harris. 1982. Oriental fruit fly: Ripening of fruit and its effect on index infestation of Hawaiian papayas. J. Econ. Entomol. 75:173-178.

Seo, S.T., B.K.S. Hu, M. Komura, C.Y.L. Lee, and E.J. Harris. 1974. Dacus doralis vapor heat treatment in papaya. J. Econ. Entomol. 67:240-242.

Seo, S.T., R.M. Kobayashi, D.L. Chambers, A.M. Dollar, and M. Hanaoka. 1973. Hawaiian fruit flies in papaya, bell pepper, and egg plant: Quarantine treatment with gamma irradiation. J. Agr. Entomol. 66:937-939.

Sharp, J.L. 1986. Hot-water treatment for control of Anastrepha suspensa (Diptera: Tephritidae) in mangos. J. Econ. Entomol. 79:706-708.

Sharp, J.L. 1989. Hot-water immersion appliance for quarantine research. J. Econ. Entomol. 82:189-192.

Sharp, J.L. 1990. Immersion in heated water as a quarantine treatment for California stone fruit infested with the Caribbean fruit fly (Diptera: Tephritidae). J. Econ. Entomol. 83:1468-1470.

Sharp, J.L., M.T. Ouye, W. Hart, S. Ingle, G. Hallman, W. Gould, and V. Chew. 1989a. Immersion of Florida mangos in hot water as a quarantine treatment for Caribbean fruit fly (Diptera: Tephritidae). J. Econ. Entomol. 82:186188.

Sharp, J.L., M.T. Ouye, S.J. Ingle, W.G. Hart, W.R. Enkerlin, H.H. Celedonio, J. Toledo, L. Stevens, E. Quintero, J. Reyes, and A. Schwarz. 1989b. Hotwater quarantine treatment for mangoes from the state of Chiapas, Mexico, infested with Mediterranean fruit fly and Anastrepha serpentina. J. Econ. Entomol. 82:1663-1666.

Sharp, J.L. and H. Picho-Martinez. 1990. Hot-water quarantine treatment to control fruit flies in mangoes imported into the United States from Peru. J. Econ. Entomol. 83:1940-1943.

Sharp, J.L. and D.H. Spalding. 1984. Hot water as a quarantine treatment for Florida mangoes infested with Caribbean fruit fly. Proc. Fla. State Hort. Soc. 97:355-357.

Sinclair, W.B. and D.L. Lindgren. 1955. Vapor heat sterilization of California citrus and avocado fruits against fruit-fly insects. J. Econ. Entomol. 48:133-138.

Smilanick, J.L. and D.C. Fouse. 1989. Quality of nectarines stored in insecticidal low- $\mathrm{O}_{2}$ atmospheres at 5 and 15C. J. Amer. Soc. Hort. Sci. 114:431436.

Smillie, R.M. and G.C. Gibbons. 1981. Heat tolerance and heat hardening in crop plants measured by chlorophyll fluorescence. Carlsberg Res. Commun. 46:395-403.

Soderstrom, E.L. 1977. Research on the use of a low oxygen atmosphere for insect control in dried fruits and tree nuts, p. 205-206. In: D.H. Dewey (ed.). Hort. Rpt. 28, Michigan State Univ., East Lansing. 
Soderstrom,E.L. and D.G. Brandl. 1984. Low oxygen atmosphere for postharvest insect control in bulk-stored raisins. J. Econ. Entomol. 77:440-445.

Soderstrom, E.L. and D.G. Brandl. 1990. Controlled atmospheres for the preservation of tree nuts and dried fruits, p. 83-92. In: M. Calderon and R. Barkai-Golan (eds.). Food preservation by modified atmospheres. CRC Press, Boca Raton, Fla.

Soderstrom, E.L., D.G. Brandl, and B. Mackey. 1990. Responses of codling moth (Lepidoptera:Torticidae) life stages to high carbon dioxide or low oxygen atmospheres. J. Econ. Entomol. 83:472-475.

Sommer, N.F. and F.G. Mitchell. 1986. Gamma irradiation-A quarantine treatment for fresh fruits and vegetables. HortScience 218:356-360.

Sommer, N.F. and F.G. Mitchell. 1987. Relation of chilling temperatures to postharvest alternaria rot of papaya fruit. Proc. Trop. Reg. Amer. Soc. Hort. Sci. 22:40.

Spiers, J., C.J. Brady, D. Grierson, and E. Lee. 1984. Changes in ribosome organization and messenger RNA abundance in ripening tomato fruits. Austral. J. Plant Physiol. 11:225-233.

Spitler, G.H., J.W. Armstrong, and H.M. Couey. 1984. Mediterranean fruit fly host status of commercial lemons. J. Econ. Entomol. 77:1441-1444.

Toba, H.H. and A.K. Burditt. 1992. Gamma irradiation of codling moth (Lepidoptera: Tortricidae) eggs as a quarantine treatment. J. Econ. Entomol. 85:464-467.

Toba, H.H. and H.R. Moffitt. 1991. Controlled atmosphere cold storage as a quarantine treatment for non-diapausing codling moth (Lepidoptera: Torticidae) larvae in apples. J. Econ. Entomol. 84:1316-1319.

Tucker, G.A. and D. Grierson. 1982. Synthesis of polygalacturonase during tomato fruit ripening. Planta 155:64-67.

Tucker, G.A., N.G. Robertson, and D. Grierson. 1980. Changes in polygalacturonase isoenzymes during the 'ripening' of normal and mutant tomato fruit. Eur. J. Biochem. 112:119-124.

U.S. Food and Drug Administration. 1986. Irradiation in the production, processing, and handling of foods; Final rules. Fed. Reg. 51:1337513399.

Vargas, R.I., E.J. Harris, and T. Nishida. 1983. Distribution and season occurrence of Certatitis capitata (Wiedemann) (Diptera: Tephritidae) on the island of Kauai in the Hawaiian Islands. J. Econ. Entomol. 12:303-310.
Vargas, R.I., D. Miyashita, and T. Nishida. 1984. Life history and demographic parameters of three laboratory-reared tephitids (Diptera: Tephritidae). Ann. Entomol. Soc. Amer. 77:651-656.

Wang, C.Y. 1982. Physiological and biochemical responses of plants to chilling stress. HortScience 17:161-186.

Wang, C.Y. 1989. Chilling injury of fruits and vegetables. Food Rev. Intl. 5:209-236.

Wardlaw, W.C. 1937. Tropical fruits and vegetables: An account of their storage and transport. Memoirs 7, Imperial College of Tropical Agriculture, Trinidad, West Indies [reprinted from Trop. Agr. (Trinidad) 14:3.]

Wardlaw, C.W. and L.P. McGuire. 1931. Banana storage. Trop. Agr.(Trinidad) 8:139.

Wit, A.K.H. 1986. Postharvest control of insects and mites. Acta Hort. 181:482.

Wu, M.T. and S.J. Wallner. 1984. Heat stress responses in cultured plant cells. Heat tolerance induced by heat shock versus elevated growing temperatures. Plant Physiol. 75:778-780.

Yahia, E.M., M. Rivera, and O. Hernandez. 1992. Response of papaya to shortterm insecticidal oxygen atmosphere. J. Amer. Soc. Hort. Sci. 117:96-99.

Yahia, E.M. and L. Vazquez-Morena. 1993. Responses of mango to insecticidal oxygen and carbon dioxide atmospheres. Lebenem Wiss. Technol. Food Sci. Technol. 25:42-48.

Yokoyama, V.Y. and G.T. Miller. 1987. High temperature for control of oriental fruit moth (Lepidoptera: Tortricidae) in stone fruit. J. Econ. Entomol. 80:641-645.

Yokoyama, V.Y., G.T. Miller, and R.V. Dowell. 1991. Responses of codling moth (Lepidoptera: Tortricidae) to high temperature, a potential treatment for export commodities. J. Econ. Entomol. 84:528-531.

Yarwood, C.E. 1961. Acquired tolerance of leaves to heat. Science 134:941942

Yoshida, O., H. Nakagawa, N. Ogura, and T. Sato. 1984. Effect of heat treatment on the development of polygalacturonase in tomato fruit during ripening. Plant Cell Physiol. 25:505-509.

Yost, H.J. and S. Lindquist. 1988. Translation of unspliced transcripts after heat shock. Science 242:1544-1548.

Yu, Y.B., D.O. Adams, and S.F. Yang. 1980. Inhibition of ethylene production by 2, 4-dinitrophenol and high temperature. Plant Physiol. 66:286-290.

\title{
PULL ISOLAB AD FROM p. 744 of JULY 1994 ISSUE
}

\author{
This is a two-color ad; second color is PMS Pantone Green C (see tear copy)
}

